Syntax Literate: Jurnal Ilmiah Indonesia p-ISSN: 2541-0849

e-ISSN: 2548-1398

Vol. 7, No. 1, Januari 2022

\title{
THE EFFECT OF YAMAMOTO NEW SCALP ACUPUNCTURE THERAPY ON LOWERING THE BLOOD PRESSURE OF HYPERTENSION PATIENTS AT A PRIMARY CARE SERVICE FAMILY MEDICINE ACUPUNCTURE CLINIC "XYZ" JAKARTA
}

\author{
Yuliawati Kusumaningrum, Mayang Wulandari, Ikhwan Abdullah, Chantika \\ Mahadini \\ Science and Technology Institute, Malang, East Java, Indonesia \\ Email: yuliawatidr03@gmail.com, mayang.wulandari2017@gmail.com, \\ ikhwana03@gmail.com, chantika.mahadini2017@gmail.com
}

\begin{abstract}
Hypertension can hinder the development of social and economic stability and can become a major threat to the structure of healthcare services. The management of hypertension cases in primary care can be performed through a family medicine approach by taking into account the potential of the family as the supporting resource and/or obstacles to the successful management of hypertension patients. This can be performed with acupuncture methods, one of which is the Yamamoto New Scalp Acupuncture (YNSA) method. Objective: To determine the effect of acupuncture therapy using YNSA method on lowering the blood pressure of patients with hypertension at the Primary Care Service Family Medicine Clinic "XYZ, Jakarta." Methods: This quantitative research uses pre-experimental and post-experimental nonrandom purposive sampling techniques which yield a total sample of 76 respondents. The sample has met certain criteria and is divided into 2 groups: the intervention group and the control group. The assessment was carried out for 7 days for each group. Conclusion: The use of the YNSA method for patients with hypertension in the two groups had significantly different results during preand post-treatment with $p<0.05$. This shows that there is a significant difference in the two groups from the second to the seventh days.
\end{abstract}

Keywords: acupuncture; YNSA; hypertension; primary care family medicine

Received: 2021-12-20; Accepted: 2022-01-05; Published: 2022-01-15

\section{Introduction}

Hypertension is another name for high blood pressure. In hypertension, there is an increase in systolic blood pressure exceeding $140 \mathrm{mmHg}$ and in diastolic blood pressure exceeding $90 \mathrm{mmHg}$ based on blood pressure measurements (Dr. Tunggul Diapari Situmorang, 2019). Hypertension can hinder the development of social and economic stability and becomes a major threat to the structure of healthcare services ( $\mathrm{Li}$ et al., 2019). Based on Riskesdas data in 2018, there was an increase from $27.8 \%$ cases of hypertension in 2013 to $34.1 \%$ in 2018 from a total population of 260 million people in

$\begin{array}{ll}\text { How to cite: } & \text { Kusumaningrum. Y., Mayang Wulandari, Ikhwan Abdullah \& Chantika Mahadini (2022) The Effect of } \\ & \text { Yamamoto New Scalp Acupuncture Therapy on Lowering The Blood Pressure of Hypertension Patients At } \\ & \text { A Primary Care Service Family Medicine Acupuncture Clinic "XYZ" Jakarta. Syntax Literate: Jurnal Ilmiah } \\ & \text { Indonesia, } 7 \text { (1). http://dx.doi.org/10.36418/ Syntax-Literate.v7i1.6022 } \\ \text { E-ISSN: } & \text { 2548-1398 } \\ \text { Published by: } & \text { Ridwan Institute }\end{array}$


The Effect of Yamamoto New Scalp Acupuncture Therapy on Lowering The Blood Pressure of Hypertension Patients At A Primary Care Service Family Medicine

Acupuncture Clinic "XYZ" Jakarta

Indonesia. This shows that there has been an increase of $6.3 \%$ of hypertension cases in Indonesia in the last 5 years (Ministry of Health, 2019) dalam (A Rahim, Ibrahim, A Salim, \& Ariffin, 2019). Common complications that often occur in patients with hypertension include coronary heart disease (CHD) and kidney failure (Klausen, Scharling, Jensen, \& Jensen, 2005). The management of hypertension can be performed through pharmacological and non-pharmacological approaches. One of the nonpharmacological treatments of hypertension is acupuncture (Nuraini, 2019). One of the micro-acupuncture techniques that have been applied is through head acupuncture or YNSA which was invented by Doctor Toshikatsu Yamamoto in 1973 (Acupuncture, 2021). YNSA is a microsystem whose action is performed through inserting needles through acupuncture points in the skull in order to stimulate reflex areas of the body. Currently YNSA is often used for the treatment of neurological disorders, acute and chronic pain, as well as functional disorders such as hypertension (Dérrick Partrick Artioli1, Marcus Vinícius Gonçalves Torres Azevedo1, 2018). This technique has no side effects and has great potential to reduce disorders in the body. At present, YNSA has been widely acknowledged in various countries such as Japan, Europe, and the United States (Barreiros et al., 2019). Based on this background, this research develops the theme of the effect of YNSA acupuncture therapy method on lowering the blood pressure of patients with hypertension at the Primary Service Family Medicine Clinic "XYZ", Jakarta.

\section{Research Method}

The quantitative research method is used with pre-experimental and postexperimental nonrandom purposive sampling techniques which yield a total sample of 76 respondents (Cresswell, 2017). The sample has met certain criteria and is divided into 2 groups: the YNSA intervention group and the control group. Research period is from 15 March 2021 - 15 May 2021. The assessment was carried out for 7 days for each group (Deni Darmawan, 2019).

The data were obtained from the 76 respondents who are evenly divided into the two groups: the YNSA intervention group and the control group, each of which consists of 38 respondents. The results of the data analyses are presented in the following sections.

\section{Discussion}

The research data were obtained by measuring the blood pressure of the respondents who came to the XYZ Primary Service Family Medicine acupuncture clinic, Jakarta, between March and May 2021. After the data collection process, 76 respondents were obtained and grouped into two: the YNSA acupuncture intervention group and the control group, each of which has 38 respondents. The YNSA intervention group experienced the needle insertions following YNSA scientific rules, while the control group experience no needle insertions. YNSA is somatotopic, so it is able to describe the representative relationship of certain anatomical and functional areas of the 
body such as the motor and sensory areas of the brain which are specific areas of the cortex that are responsible for motor and sensory control of various areas of the body through the correspondence points of the central nervous system whose efficacy and procedure have been reported to be similar to Chinese acupuncture in general. Animal testing and clinical trials have also shown that the antihypertensive effect with a proper selection of points is one of the main factors that influence blood pressure lowering processes. This means that YNSA can contribute to the mechanisms of hypertension. YNSA can lower the blood pressure and protect target organs (Kamiya et al., 2021).

\section{Conclusion}

The use of YNSA method for patients with hypertension in the two groups had significantly different results during pre- and post-treatment with $\mathrm{p}<0.05$. This shows that there is a significant difference in the two groups from the second to the seventh day. The mean value of systolic blood pressure in the YNSA intervention group was 147,105 with the standard deviation of 7.9416 , and the standard error of the mean was 1.2883. Nevertheless, the control group without YNSA intervention had the mean systolic blood pressure value of 141.789 with the standard deviation of 8.7183 , and the standard error of the mean is 1.4143. The findings indicate that the intervention with Yamamoto New Scalp Acupuncture was proven to significantly lower blood pressure when compared to the treatment before the intervention with YNSA. This means YNSA was proven to significantly lower the blood pressure. 
The Effect of Yamamoto New Scalp Acupuncture Therapy on Lowering The Blood Pressure of Hypertension Patients At A Primary Care Service Family Medicine Acupuncture Clinic "XYZ" Jakarta

\section{BIBLIOGRAFI}

A Rahim, Afiq Izzudin, Ibrahim, Mohd Ismail, A Salim, Faizul Nizam, \& Ariffin, Mohd Ariff Ikram. (2019). Health information engagement factors in Malaysia: a content analysis of Facebook use by the Ministry of Health in 2016 and 2017. International Journal of Environmental Research and Public Health, 16(4), 591. Google Scholar

Acupuncture. (2021). "Merriam Webster", diunduh, 30 Januari 2021, 23.00. Retrieved from https://www.merriam-webster.com/dictionary/acupuncture

Barreiros, Raphael Neves, Dutra, Luana Borges, da Silva, Roberto Carlos Lyra, Ribeiro, Yonara Cristiane, Louro, Lidiane da Fonseca Moura, \& Louro, Thiago Quinellato. (2019). The Japanese Scalp Acupuncture as an Instrument for Non-Specific Pain Treatment in Health Professionals/A Craniopuntura Japonesa como Instrumento para o Tratamento da Dor não Específica em Profissionais de Saúde. Revista de Pesquisa Cuidado é Fundamental Online, 11(3), 594-598. Google Scholar

Cresswell, J. W. (2017). Research Design: Pendekatan Kualitatif, Kuantitatif, dan Mixed (Edisi Ketiga). Yogyakarta: Pustaka Belajar. Google Scholar

Deni Darmawan. (2019). Metode Penelitian Kuantitatif. Bandung Rosdaya. Google Scholar

Dérrick Partrick Artioli1, Marcus Vinícius Gonçalves Torres Azevedo1, Gladson Ricardo Flor Bertolin. (2018). "YNSA: its applications and results in painful conditions. Systematic review.” Br J Pain. São Paulo, 1(2), 180-183.

Dr. Tunggul Diapari Situmorang. (2019). Konsensus Penatalaksanaan Hipertensi 2019. Google Scholar

Kamiya, Tetsuharu, Suematsu, Takuya, Omata, Fumiya, Kasukabe, Sachie, Suzuki, Manami, Kaneko, Soichiro, Takayama, Shin, \& Ishii, Tadashi. (2021). Safety of Yamamoto New Scalp Acupuncture in Healthy Subjects and the Relationship Between Shoulder Stiffness, Diagnosis Points, and Stimulation Points. Acupuncture \& Electro-Therapeutics Research, 46(2), 111-122. Google Scholar

Klausen, Klaus Peder, Scharling, Henrik, Jensen, Gorm, \& Jensen, Jan Skov. (2005). New definition of microalbuminuria in hypertensive subjects: association with incident coronary heart disease and death. Hypertension, 46(1), 33-37. Google Scholar

Li, Juan, Sun, Mingsheng, Ye, Jing, Li, Yuxi, Jin, Rongjiang, Zheng, Hui, \& Liang, Fanrong. (2019). The mechanism of acupuncture in treating essential hypertension: A narrative review. International Journal of Hypertension, 2019. Google Scholar

Nuraini. (2019). “Risk Factors Of Hypertension.” Uke.Kedokteran.Unila.Ac.Id, 4(5). 
Yuliawati Kusumaningrum, Mayang Wulandari, Ikhwan Abdullah, Chantika Mahadini

\section{Copyright holder:}

Yuliawati Kusumaningrum, Mayang Wulandari, Ikhwan Abdullah, Chantika Mahadini (2022)

First publication right:

Syntax Literate: Jurnal Ilmiah Indonesia

This article is licensed under:

(c) (†) (?) 